\title{
Forysta sem samstarfsverkefni: Áhersla skólastjóra á valddreifingu og samstarf
}

\author{
Börkur Hansen og Steinunn Helga Lárusdóttir \\ Abstract \\ Um höfundana \\ About the authors \\ - Heimildir
}

Í nútímakenningum um skólastjórnun er kastljósinu jafnan beint að sýn skólastjóra á hlutverk sitt og tengsl við samstarfsfólk. Pá er átt við að skólastjórar og kennarar starfi saman að pví að próa skólastarf og kennsluhætti. Markmiðið með slíkum starfsháttum er að stuðla að auknum gæðum í skólastarfi. Í pessari grein er athyglinni beint að peim afbrigðum samstarfsforystu sem fengið hafa mikið rými í fræðilegri umræðu á 21. öldinni, p.e. dreifðri forystu (e. distributed leadership) og kennaraforystu (e. teacher leadership). Gögnum var safnað með spurningakönnun sem send var til allra skólastjóra vorið 2017 og var svarhlutfallið 69\%. Í niðurstöðum er dregin upp mynd af aðstæðum í skólunum og greint frá hversu miklum tíma skólastjórar telja sig verja til samstarfs við millistjórnendur, kennara og annað starfsfólk, hversu mikla áherslu peir leggja á pátttöku millistjórnenda og kennara í ákvörðunum og virkja pá til forystu um próun kennsluhátta. Í umræðunum um niðurstöðurnar er bent á mikilvægi pess að skólastjórar horfi gagnrýnið á hvert markmiðið með virkjun millistjórnenda og kennara er, p.e. hvort pað sé einkum til að létta vinnuálagi af skólastjórum eða til að dreifa forystu um próun náms og kennslu. Pá parf að greina hvort launamál, vinnuálag eða aðrir starfstengdir pættir valdi pví að meirihluta skólastjóra veitist erfitt að virkja kennara til kennslufræðilegrar forystu í págu skólastarfsins alls.

Efnisorð: Skólastjórar, grunnskólar, dreifð forysta, kennaraforysta

\section{Inngangur}

Krafan um breytingar og próun skólastarfs er síung. Fyrir áratug birtist grein eftir höfunda undir nafninu „Breytingar á hlutverki skólastjóra í grunnskólum. Kröfur, mótsagnir og togstreita“ (Börkur Hansen, Ólafur H. Jóhannsson og Steinunn Helga Lárusdóttir, 2008). Greinin hófst á orðunum „Umtalsverðar breytingar á ytra umhverfi grunnskóla hafa átt sér stað á síðustu árum“ og var pá miðað við áratuginn á undan. Í greininni var athyglinni beint að breytingum á lagaumhverfi skóla og peim áhrifum sem pær hefðu haft á störf skólastjóra. Vísað var til grunnskólalaga frá 1995 (lög um grunnskóla nr. 66/1995) en með peim hefði fjárhagsleg ábyrgð skólastjóra aukist, áhersla verið lögð á mat á skólastarfi, endurmenntun starfsmanna, próunarstarf, aukið samráð við kennara og aukið samráð og upplýsingagjöf til foreldra (Börkur Hansen o.fl., 2008).

Á peim rúma áratug sem liðinn er frá birtingu pessarar greinar hefur ytra umhverfi skóla og starfsumhverfi skólastjóra breyst vegna lagalegra, albjóðlegra og fræðilegra áhrifa. Lagaramminn hefur breyst með nýjum grunnskólalögum og aðalnámskrá. Alpjóðlegir menntapólitískir straumar hafa m.a. orðið til pess að auka kröfur til skóla um árangur sem fylgt er eftir með auknu eftirliti og fjölbjóðlegum samanburði. Í fræðilegum skrifum hefur verið lögð áhersla á að dreifa forystunni pannig að skólastjórar, millistjórnendur (e. middle leaders) og almennir kennarar séu sameiginlega í forystu fyrir skólastarfið. Nýlegar rannsóknir benda einmitt til pess að samstarf 
ráđi miklu um gæði skólastarfs (Anrig, 2015; McCarthy og Rubinstein, 2017; Rubinstein, 20132014). Dví er mikilvægt að varpa ljósi á pað hvort og pá hvernig samstarfi i íslenskum grunnskólum er háttað.

Í pessari grein er athyglinni beint að forystu sem samstarfsverkefni skólastjóra, millistjórnenda (deildarstjóra, stigsstjóra, fagstjóra, o.s.frv.) og kennara. Athyglinni er beint að peim afbrigðum samstarfsforystu sem fengið hafa mikið rými í fræðilegri umræðu á 21. öldinni, p.e. dreifðri forystu (e. distributed leadership) og kennaraforystu (e. teacher leadership). Kannað var hversu miklum tíma skólastjórar verja til samstarfs við millistjórnendur, almenna kennara og aðra starfsmenn. Einnig var kannað hversu mikla áherslu skólastjórar leggja á að sömu aðilar taki pátt í ákvörðunum um mikilvæg málefni og hversu mikla áherslu peir leggja á að millistjórnendur og kennarar séu leiðandi um próun kennsluhátta. Niðurstöður eru ræddar með vísan í fræðileg skrif um forystu á síðustu árum.

\section{Fræðilegt samhengi}

\section{Forysta sem samstarfsverkefni}

Í skýrslunni How the World's Most Improved School Systems Keep Getting Better kemur fram að samstarf sé lykilpáttur í að stuðla að umbótum í skólastarfi (Mourshed, Chijioke og Barber, 2010; Woolfolk-Hoy og Hoy, 2009). Segja höfundar að mikil áhersla á samstarf og hópvinnu hafi birst sem rauður práđur í starfsemi allra skóla í peim tuttugu löndum sem um ræđir. Í formála skýrslunnar segir skólafrömuðurinn Michael Fullan að pað séu einkum tvær ástæður sem skýri gildi samstarfs: Með samstarfi nýtist pekking margra við lausn vandamála og mikið samstarf stuðli jafnframt að aukinni samsömun starfsfólks við hlutverk sitt. Anrig (2015), McCarthy og Rubinstein (2017) og Rubinstein (2013-2014) segja að mikill fjöldi rannsóknarniðurstaðna bendi til pess að samstarf af öllu tagi stuðli að betri námsárangri, minna brottfalli úr starfi og hafi auk pess víðtæk jákvæð áhrif á skólamenningu.

Dessar áherslur koma ekki á óvart pví margir samtímafræðimenn telja einmitt að forysta snúist fyrst og fremst um samskipti (Branson, Franken og Penney, 2016; Sergiovanni, 2009; Spillane, 2006). Í fræðilegum skrifum birtist pessi afstaða í pví að lögð er áhersla á stjórnun og forystu sem samstarfsverkefni skólastjórnenda og kennara. Pegar svo háttar leiða formlegir stjórnendur og kennarar skólastarfið í sameiningu með pað markmið að stuðla að auknum gæðum í skólastarfi (Hoy og Miskel, 2008; Sergiovanni, 2009; Woolfolk-Hoy og Hoy, 2009). Petta getur pví aðeins gerst ef skólastjórum tekst að nýta sér fjölbreytileikann í starfsmannahópnum (Lumby, 2013).

Í pessu samhengi er talið mikilvægt að starfsfólk skóla eigi aðild að ákvörðunum um mikilvæg málefni. Viðamikil rannsókn Louis, Leithwood, Wahlstrom og Anderson (2010) leiddi meðal annars 1 ljós að í peim skólum sem taldir voru hafa nád miklum árangri (e. high performing) var pátttaka og hlutdeild kennara 1 ákvörðunum mun meiri en í peim skólum sem taldir voru hafa náð litlum árangri (e. low performing).

Margar hugmyndir og kenningar um forystu sem samstarfsverkefni hafa verið kynntar til sögunnar síðustu tvo áratugi. Meðal peirra eru samráðsforysta (e. collaborative leadership), lýðræðisleg forysta (e. democratic leadership), pátttökumiðuð forysta (e. participative leadership), teymisforysta (e. team leadership) og dreifð forysta (e. distributed leadership). Hér verður athyglinni fyrst og fremst beint að umfjöllun um dreifða forystu og kennaraforystu (e. teacher leadership).

\section{Dreifo forysta}

Frá síðustu aldamótum hefur kenningin um dreifða forystu verið ráðandi bæði í fræðilegum skrifum og á vettvangi skóla víða á Vesturlöndum (Bush, 2013; Harris, 2008; Steinunn Helga 
Lárusdóttir og O’Connor, 2017). Að mati Lumby (2013) er dreifð forysta sú kenning sem hlotið hefur mesta athygli.

Fjölmargar lýsingar eru til á dreifðri forystu og hefur umfjöllun um hugtakið liðið fyrir pann ólíka skilning sem lagður er í pað (Börkur Hansen og Steinunn Helga Lárusdóttir, 2016). Merking hugtaksins hefur einnig skarast við önnur skyld hugtök eins og samráðsforystu, lýðræðislega forystu, pátttökumiðaða forystu o.fl. Ýmislegt greinir pessi hugtök að en sameiginleg er sú afstaða að forystan skuli ekki vera á höndum eins einstaklings heldur sé hún samstarfsverkefni.

Merking ofangreindra hugtaka skarast einnig við dreifða forystu, eins og henni er lýst af Spillane, helsta kenningasmiði dreifðrar forystu (Harris, 2008). Dreifð forysta hefur eigi að síður nokkra sérstöðu. Að mati Spillane (2006) verður forysta eingöngu til í samskiptum. Forysta er pannig félagslegt afl sem skapast í samskiptum innan stofnunar, afl sem verður til pegar tekist er á við hagnýt verkefni. Slík forysta er óhád formlegum embættum (Börkur Hansen, 2013). Samkvæmt pessari skilgreiningu Spillane er forysta hvorki í höndum skólastjóra, millistjórnenda né kennara heldur er hún afurð af innbyrðis samskiptum peirra um pau málefni sem um ræðir hverju sinni. Aðstæðurnar (e. context) par sem samskiptin eiga sér stað skipta miklu máli pví pær hafa áhrif á hvernig pau próast og hver afurð peirra verður (Spillane, 2006).

\section{Kennaraforysta}

Til viðbótar við kennara sem gegna formlegum stöðum millistjórnenda hafa fræðimenn fjallað um svonefnda forystukennara (e. teacher leaders). Í pessu sambandi telur Harris (2008) mikilvægt að hafa í huga að forysta í skólum geti verið dreifð meðal starfsfólks án pess að vera bundin við formleg embætti á sviði stjórnunar. Forysta getur pví orðið til meðal starfsfólks par sem fjölbreyttur hópur einstaklinga er leiðandi um tiltekin málefni, svo sem um kennslu og kennsluhætti. Með pví að kalla fleiri kennara til forystu en pá sem gegna formlegum stöðum millistjórnenda er viðurkennt að sérhver starfsmaður skóla búi yfir forystuhæfni sem hópurinn hafi pörf fyrir á einhverjum tímapunkti (Harris, 2008, 2013; Spillane, 2005). Kennaraforysta er pá ein birtingarmynd pessarar útgáfu af dreifðri forystu og hún verður til í samskiptum kennara ef skólamenningin er samstarfsmiðuð. Akert og Martin (2012) benda á að skólastjórinn beri ábyrgð á pví að skapa skólamenningu par sem kennarar sækjast eftir og eru hvattir til að vera í forystu. Dað er pví undir skólastjóranum komið að skapa rými fyrir pá kennara sem vilja veita forystu um tiltekin verkefni.

Hlutverki forystukennara hefur verið lýst á ýmsa vegu. Katzenmeyer og Moller (2001) og Ash og Persall (2000) gera t.a.m. lítinn greinarmun á hlutverki kennara í formlegum millistjórnendastöðum og kennurum sem gegna óformlegu hlutverki á sviði stjórnunar. Að peirra mati geta pví forystukennarar verið í óformlegu forystuhlutverki gagnvart nemendum og ráðgjafar kennara en líka í formlegu hlutverki sem millistjórnendur.

Deir eru pó fleiri sem gera skýran greinarmun á pessu tvennu. Algengt er að forystukennurum sé lýst sem bekkjarkennurum er veita forystu á einhverju sviði án pess að gegna formlegri stjórnunarstöðu (Akert og Martin, 2012; Muijs og Harris, 2003). Önnur og svipuð afstaða er sú að um sé að ræða kennara með forystuhæfileika sem vilja halda áfram að kenna en deila jafnframt sérhæfingu sinni og pekkingu með öðrum kennurum (Danielson, 2006; York-Barr og Duke, 2004). Að mati Ash og Persall (2000) er rauði práđurinn í skrifum fræðimanna sá að forystukennarar séu afburðakennarar (e. expert teachers) sem verji mestum tíma sínum í kennslustofunni, en takist einnig á við mismunandi forystuhlutverk utan hennar á ólíkum tímum.

Allar eiga pessar lýsingar pað sameiginlegt að í peim er litið svo á að forystukennarar sinni fyrst og fremst kennslu en séu jafnframt í óformlegu forystuhlutverki um tiltekin viðfangsefni, einkum kennslu og kennsluhætti. Áherslan á hlutverk forystukennara sem kennslufræðilegra leiðtoga kemur skýrt fram í eftirfarandi skilgreiningu Patterson og Patterson (2004, bls. 74): 
[Kennaraforysta er] ferli par sem einstakir kennarar eða kennarahópar hafa áhrif á samkennara sína, skólastjórann eða aðra í skólasamfélaginu í peim tilgangi að auka gæði náms og kennslu og stuðla pannig að betri námsárangri nemenda.

Day og Harris (2002) taka saman helstu rannsóknarniðurstöður varðandi hlutverk forystukennara og tilgreina í pví sambandi eftirfarandi pætti:

1. Að tryggja að umbótaáform skili sér inn í kennslustofur

2. Að stuðla að almennri pátttöku kennara í próunarverkefnum og að peir finni fyrir eignarhaldi á peim

3. Að veita kennurum upplýsingar og sérfræðiaðstoð svo að peir séu færir um að leggja gagnrýnið mat á tilboð um stuðning

4. Að skapa farveg fyrir gagnkvæmt nám kennara með pví að mynda sterk tengsl við einstaka kennara

Hugmyndafræðin um kennaraforystu er af sama meiði og um dreifða forystu að öðru leyti en pví að gengið er enn lengra í að virkja kennara til forystu. Íslenskar rannsóknir benda til að meginmunurinn á stöðu millistjórnenda og forystukennara sé sá að forystukennarar gegni óformlegu, ólaunuðu forystuhlutverki og að peir sinni kennslu samhliða forystuhlutverki sínu. Meginviðfangsefni peirra eru á sviði náms og kennslu. Á hinn bóginn gegna millistjórnendur formlegri, launaðri stjórnunarstöðu, ýmist í hlutastarfi eða fullu starfi og hafa sérstakt starfsheiti. Stjórnunarleg viðfangsefni peirra virðast fremur vera af rekstrarlegum en kennslufræðilegum toga (Börkur Hansen og Steinunn Helga Lárusdóttir, 2016, Steinunn Helga Lárusdóttir og O’Connor, 2017).

Flestir geta án efa veitt forystu á tilteknu sviði. Dað pýðir pó ekki að allir séu eða ættu að vera leiðtogar heldur að skapaðar séu aðstæður fyrir lýðræðislega og samstarfsmiðaða forystu (Muijs og Harris, 2003). Hér gildir hið sama og um millistjórnendur að samstarf skólastjóra og kennara er talið nauðsynleg forsenda pess að hægt sé að leggja áherslu á kennaraforystu (Akert og Martin, 2012; Birky, Shelton og Headley, 2006).

\section{Gagnrýni}

Dreifð forysta hefur talsvert verið gagnrýnd, einkum útfærsla hennar á vettvangi skólans. Kenningalegur grunnur hennar hefur einnig verið talinn of veikur til að réttlætanlegt sé að nýta hana á vettvangi (Busher, Hammersley-Fletcher og Turner, 2007; Hartley, 2010). Sett hafa verið spurningarmerki við pá hvata sem liggja að baki áherslunni á dreifða forystu (Fitzgerald og Gunter, 2008; Hall, Gunter og Bragg, 2012; Hargreaves og Fink, 2008; Lumby, 2013). Pannig hefur pví til dæmis verið haldið fram að áherslan á dreifða forystu sé fyrst og fremst blekkingarleikur (e. delusional twist) par sem kennurum og millistjórnendum sé talin trú um að peir séu aðilar að pátttökumiðaðri stjórnun (Hall o.fl., 2012). Raunin sé sú að peir séu áfram hluti af prepskiptu valdakerfi par sem forystan er miðstýrð (e. leader centric) pví pað sé skólastjórinn einn sem hafi vald til að velja fólk til forystustarfa.

Um bæði hugtökin gildir að ekki er eining um merkingu peirra. Bent hefur verið á að dreifð forysta sé t.d. oft talin ná yfir alla stjórnunarhætti sem fela í sér samstarf eða hugtakið talið vera samheiti við önnur skyld hugtök (Börkur Hansen og Steinunn Helga Lárusdóttir, 2016; Tian, Risku og Collin, 2016). Fitzgerald og Gunter (2008) segjast hafa áhyggjur af pví að hugtakið kennaraforysta „hafi læett sér inn í orðaforða menntavísinda án nægilegrar umræðu um hugtakið, notkun pess og misnotkun í skólum“ (bls. 331). Svipuð gagnrýni kemur fram hjá York-Barr og Duke (2004) sem telja að skilgreiningar á hugtakinu kennaraforysta séu ekki nægilega skýrar auk pess sem lítið sé vitað um hvernig kennaraforysta próist á vettvangi og hver áhrif hennar eru. 


\section{Forysta í íslenskum grunnskólum}

Með grunnskólalögunum 1995 færðist forsjá grunnskólanna frá ríki til sveitarfélaga. Í framhaldinu breyttu skólar smám saman stjórnskipulagi sínu með pað í huga að dreifa forystunni innan skólanna.

Með kjarasamningum kennara árið 2001 kom inn ákvæði um aukinn stjórnunarkvóta og pá varð mögulegt að fjölga stjórnendum. Samningurinn sýnir að skólum var veitt umtalsvert sjálfstæði til að ráđstafa stjórnunarheimildum. Par kemur fram að skólastjóri ráðstafi vinnu kennara til faglegra starfa. Orðalagið bendir til að störf peirra kennara sem urðu millistjórnendur teldust mikilvæg fyrir próun náms og kennslu. Textinn gefur jafnframt til kynna að kennurum var ætlað hlutverk umfram framlag sitt til bekkjarkennslu og bent var á að með samnignum væri verið að leggja aukna ábyrgð á hendur kennara (Kjarasamingur Kennarasambands Íslands og fjármálaráðherra 2001-2004; Kjarasamningur kennara, 2004).

Texti kjarasamningsins vísar fyrst og fremst til formlegra millistjórnenda en getur pó vel átt við um aðra kennara sem hafa vilja og getu til að vera í forystu. Slíkir einstaklingar veita kennaraforystu eins og fræðin lýsa henni (Kjarasamingur Kennarasambands Íslands og fjármálaráðherra 2001-2004).

Nokkrar rannsóknir hafa verið gerðar á hlutverki og áherslum íslenskra millistjórnenda (sjá t.d. Börkur Hansen og Steinunn Helga Lárusdóttir, 2016; Jón Páll Haraldsson, 2015; Júlíana Hauksdóttir, 2012; Sigríður Anna Guðjónsdóttir, Amalía Björnsdóttir og Ólafur H. Jóhannsson, 2007). Dær varpa ljósi á stöðu og hlutverk millistjórnenda, sýn peirra á eigið hlutverk og væntingar annarra. Lítið er hins vegar vitað um hvort kennarar sem ekki gegna formlegum stjórnunarstöðum veita forystu um viðfangsefni sem snerta skólann í heild.

Í ljósi pess að pað er skólastjórinn sem ráđstafar vinnu kennara og annarra starfsmanna er áhugavert að kanna að hvaða marki skólastjórar leggja áherslu á samstarf við starfsmenn í starfi sínu. Skólastjórarnir voru spurðir hversu miklum tíma peir teldu sig verja til samstarfs, hversu mikla áherslu peir legðu á pátttöku kennara í ákvörðunum og hversu mikla áherslu peir legðu á að virkja pá til forystu um próun kennsluhátta.

\section{Аðferð}

\section{Pátttakendur og framkvæmd}

Vorið 2017 var spurningalisti á rafrænu formi sendur á netföng allra starfandi skólastjóra í grunnskólum landsins, samtals 162. Menntavísindastofnun sá um gerð, fyrirlögn og úrvinnslu spurningalistans. Spurningalistinn var forprófaður tvisvar sinnum með pví að leggja hann fyrir fjóra aðstoðarskólastjóra hvoru sinni. Fjórar ítrekanir voru sendar. Alls bárust 111 svör og reyndist svarhlutfallið vera 69\%. Svarendum var heitið trúnaði og við úrvinnslu komu nöfn svarenda hvergi fram. Spurningalistinn var gerður í Qualtrics og úrvinnslan í forritunum SPSS og Excel.

\section{Gerð og greining spurningalistans}

Eins og fram kemur hér að framan skiptir máli hvaða sýn skólastjórar hafa á hlutverk sitt, p.e. hvernig peir tengjast samstarfsfólki og virkja millistjórnendur og kennara til ábyrgðar og ákvarðana fyrir starfsemi sinna skóla. Í spurningalistanum voru pví settar fram spurningar sem tóku til pess hversu miklum tíma skólastjórar vörðu til samstarfs með millistjórnendum, hversu mikla áherslu peir lögðu á pátttöku peirra í ákvörðunum um skólastarfið og hve mikla áherslu peir lögðu á að millistjórnendur og almennir kennarar veittu forystu um próun náms og kennslu. Dá var aflað upplýsinga um bakgrunn skólastjóranna og aðstæður í skólunum sem peir störfuðu við. 
Svarmöguleikar voru á fimm prepa Likert-kvarða frá mikið til lítið. Valkosturinn „á ekki við“ var hafður með sem svarmöguleiki par sem aðstæður í skólunum geta verið mismunandi, s.s. að par séu engir millistjórnendur og engir aðrir starfsmenn.

Á grundvelli bakgrunnsupplýsinga voru svörin við neðangreindum spurningum skoðuð og greind, en petta eru pættir í starfsumhverfi í skólastarfi sem ætla má að geti haft áhrif á áherslur í starfi skólastjóranna: Um skólastjórana (aldur, kyn, menntun, starfsreynsla sem skólastjóri og sem aðstoðarskólastjóri) og aðstæður í skólunum (skólastærð, staðsetning skóla (höfuðborgarsvæði, landsbyggð), ríkjandi kennslufyrirkomulag (bekkjarkennsla, teymiskennsla, blanda af bekkjarkennslu og teymiskennslu), fjöldi nemenda með sértæka námsörðugleika, fjöldi annarra starfsmanna en kennara.

- Hversu miklum tíma verð pú í samstarf við millistjórnendur, kennara og annað starfsfólk (fundir, viðræður, ráðningar, ráðgjöf og stuðningur, mat o.fl.)?

- Hversu mikla áherslu leggur pú á að millistjórnendur og kennarar taki pátt 1 ákvörðunum um mikilvæg málefni?

- Hversu mikla áherslu leggur bú á að millistjórnendur og kennarar séu leiðandi um próun kennsluhátta?

Við úrvinnsluna var stuðst við kí-kvaðrat marktæknipróf og miðað við a.m.k. 95\% öryggismörk $(\mathrm{p} \leq 0,05)$ samanber bakgrunnsupplýsingar sem tilgreindar eru hér fyrir ofan.

\section{Niðurstöður}

Hér á eftir verða niðurstöður rannsóknarinnar kynntar. Fyrst er dregin upp mynd af bakgrunni skólastjórnenda og aðstæðum í skólunum en hlutverk og viðfangsefni stjórnenda geta mótast af pessum páttum.

\section{Aðstæður}

Eins og áđur segir svöruðu 111 skólastjórar í grunnskólum spurningalistanum, sem er 69\% svarhlutfall. Um 38\% svarenda voru karlar og 62\% konur. Um 13\% skólastjóranna voru 39 ára eða yngri, 26\% 40-49 ára, 43\% 50-59 ára og 17\% 60 ára eða eldri. 31\% skólastjóranna sögðust hafa starfsreynslu sem skólastjóri í 1-6 ár, 44\% í 7-15 ár og 26\% í 16 ár eða meira. Dá sögðust 47\% hafa 1-6 ára reynslu sem aðstoðarskólastjóri, 44\% 7-15 ár og 10\% í 16 ár eða meira. Um 38\% skólastjóranna reyndust vera með framhaldsnám í stjórnun og 16\% með framhaldsnám af öðru tagi. Flestir störfuðu í skólum sem eru heildstæðir (1.-10. bekkur) eða um 97\%. Um 24\% skólanna eru á Stór-Reykjavíkursvæðinu (8\% í Reykjavík og 16\% á höfuðborgarsvæðinu utan Reykjavíkur) og 76\% á öðrum stöðum.

Stærð skólanna var talsvert mismunandi, en 35\% skólanna eru með 100 eða færri nemendur, 30\% mеð 101-300 nemendur, 17\% með 301-500 nemendur og 19\% með 501 eða fleiri nemendur. Pá voru 73\% skólanna með 20 eða færri aðra starfsmenn og um 27\% með 21-60 aðra starfsmenn. Um tveir priðju peirra skóla sem voru með 20 eða færri aðra starfsmenn voru með 149 nemendur eða færri. Í 70\% skólanna var fjöldi nemenda með sértæka námsörðugleika 30 eða færri, 17\% skólanna með 31-90, og 13\% skólanna með 91 eða fleiri nemendur með sértæka námsörðugleika.

Bekkjarkennsla (kennsla í höndum umsjónarkennara eða faggreinakennara) var ráđandi kennslufyrirkomulag í 38\% skólanna, teymiskennsla (tveir eða fleiri kennarar samábyrgir fyrir kennslu í árgangi eða aldursblönduðum hópi að öllu leyti eða að hluta) í 11\% skólanna, og blandaðir kennsluhættir (blanda af bekkjarkennslu og teymiskennslu) í 39\% skólanna. Annað fyrirkomulag var í 11\% skólanna. 


\section{Samstarf}

Í spurningakönnuninni tóku prjár spurningar til tíma sem skólastjórar verja til samstarfs og eru niðurstöðurnar settar fram í töflu 1.

Tafla 1. Hlutfall (\%) pess tíma sem skólastjórar töldu sig verja til samstarfs við kennara, millistjórnendur og annað starfsfólk.

\begin{tabular}{lcccccc}
\hline & $\begin{array}{l}\text { mjög } \\
\text { litlum }\end{array}$ & litlum & $\begin{array}{l}\text { hvorki litlum } \\
\text { né miklum }\end{array}$ & miklum & $\begin{array}{l}\text { mjög } \\
\text { miklum }\end{array}$ & $\begin{array}{l}\text { á ekki } \\
\text { við }\end{array}$ \\
\hline $\begin{array}{l}\text { Hversu miklum tíma verð pú } \\
\text { í samstarf við kennara (fundir, } \\
\text { viðræður, ráðningar, ráðgjöf } \\
\text { og stuðningur, mat o.fl.) }\end{array}$ & 0 & 1 & 20 & 58 & 21 & 0 \\
\hline $\begin{array}{l}\text { Hversu miklum tíma verð pú } \\
\text { í samstarf við millistjórnendur } \\
\text { (fundir, viðræður, ráðningar, }\end{array}$ & 1 & 1 & 14 & 29 & 30 & 25 \\
ráðgjöf og stuðningur, mat \\
o.fl.)
\end{tabular}

Í töflu 1 kemur fram að skólastjórar segjast almennt verja talsverðum tíma til samstarfs við kennara, millistjórnendur og annað starfsfólk. Рað vekur athygli hve hátt hlutfall skólastjóranna segist verja miklum eða mjög miklum tíma til samstarfs við ofangreinda aðila, p.e. $79 \%$ segjast verja mestum tíma til samstarfs við kennara, 59\% við millistjórnendur og $48 \%$ við annað starfsfólk.

Á grundvelli bakgrunnsupplýsinga um skólastjórana og skólana voru svörin við ofangreindum spurningum skoðuð og greind. Engin marktæk tengsl komu fram.

\section{Dátttaka í ákvörðunum}

Tvær spurningar tóku til tíma sem skólastjórar verja til pátttöku í ákvörðunum og eru niðurstöðurnar setar fram í töflu 2.

Tafla 2. Hlutfall (\%) skólastjóra um pá áherslu sem peir leggja á pátttöku kennara og millistjórnenda í ákvörðunum.

\begin{tabular}{lcccccc}
\hline & $\begin{array}{l}\text { mjög } \\
\text { litið/litla }\end{array}$ & $\begin{array}{l}\text { lítið/ } \\
\text { litla }\end{array}$ & $\begin{array}{l}\text { hvorki lítið } \\
\text { né mikið }\end{array}$ & $\begin{array}{l}\text { mikið/ } \\
\text { mikla }\end{array}$ & $\begin{array}{l}\text { mjög mikið/ á ekki } \\
\text { mikla }\end{array}$ & $\begin{array}{l}\text { við } \\
\text { við }\end{array}$ \\
\hline $\begin{array}{l}\text { Hversu mikla áherslu leggur pú á að } \\
\text { kennarar taki pátt í ákvörðunum um } \\
\text { mikilvæg málefni? }\end{array}$ & 0 & 0 & 0 & 43 & 53 & 0 \\
\hline $\begin{array}{l}\text { Hversu mikla áherslu leggur pú á að } \\
\text { millistjórnendur taki pátt í ákvörðun- } \\
\text { um um mikilvæg málefni? }\end{array}$ & 1 & 0 & 0 & 8 & 66 \\
\hline
\end{tabular}


Í töflu 2 kemur fram að langflestir skólastjóranna segjast leggja mikla eða mjög mikla áherslu á pátttöku kennara og millistjórnenda í ákvörðunum um mikilvæg málefni. Engin marktæk tengsl komu fram á grundvelli greiningar með bakgrunnsupplýsingum um skólastjórana og skólana.

\section{Forysta}

Í spurningalistanum var premur spurningum beint að forystuhlutverki skólastjóra, p.e. hversu mikla áherslu peir legðu á að virkja millistjórnendur og kennara í að vera leiðandi um próun kennsluhátta og hversu mikið peir segðust purfa að leggja á sig við að fela kennurum ábyrgð á viðfangsefnum utan kennslustofunnar, p.e. málefnum sem taka til skólastarfs almennt. Niðurstöðurnar eru settar fram í töflu 3.

Tafla 3. Hlutfall (\%) skólastjóra um hversu mikla áherslu peir leggja á virkjun millistjórnenda og kennara í að vera leiðandi um próun kennsluhátta og að fela kennurum ábyrgð.

\begin{tabular}{|c|c|c|c|c|c|c|}
\hline & $\begin{array}{l}\text { mjög } \\
\text { litid } \\
\text { litla } \\
\end{array}$ & $\begin{array}{l}\text { lítid/ } \\
\text { litla }\end{array}$ & $\begin{array}{l}\text { hvorki } \\
\text { lítið né } \\
\text { mikið }\end{array}$ & $\begin{array}{l}\text { mikid/ } \\
\text { mikla }\end{array}$ & $\begin{array}{l}\text { mjög } \\
\text { mikið/ } \\
\text { mikla }\end{array}$ & $\begin{array}{l}\text { á ekki } \\
\text { vid }\end{array}$ \\
\hline $\begin{array}{l}\text { Hversu mikla áherslu leggur pú á að } \\
\text { millistjórnendur séu leiðandi um próun } \\
\text { kennsluhátta? }\end{array}$ & 0 & 0 & 8 & 11 & 55 & 26 \\
\hline $\begin{array}{l}\text { Hversu mikla áherslu leggur pú á að } \\
\text { einstakir kennarar séu leiðandi um } \\
\text { próun kennsluhátta? }\end{array}$ & 0 & 0 & 3 & 33 & 61 & 2 \\
\hline $\begin{array}{l}\text { Hversu mikið parft pú að leggja á pig til } \\
\text { að virkja kennara og fela peim ábyrgð á } \\
\text { viðfangsefnum utan kennslustofunnar? }\end{array}$ & 1 & 2 & 30 & 32 & 32 & 2 \\
\hline
\end{tabular}

Eins og fram kemur í töflu 3 pá sögðust langflestir skólastjóranna leggja mikla eđa mjög mikla áherslu á að bæði millistjórnendur og kennarar væru leiðandi um próun kennsluhátta. Athygli vekur að 64\% eða um tveir priðju hluta skólastjóranna sögðust purfa að leggja mikið eða mjög mikið á sig til að virkja kennara og fela peim ábyrgð. Enginn marktæk tengsl komu fram á grundvelli greiningar með bakgrunnsupplýsingum um skólastjórana og skólana.

\section{Umræða}

Í pessari grein er kastljósinu beint að forystu sem samstarfsverkefni. Kannað var hversu miklum tíma skólastjórar í grunnskólum vörðu til samstarfs við millistjórnendur, almenna kennara og aðra starfsmenn. Pá var kannað hversu mikla áherslu skólastjórar legðu á að sömu aðilar tækju pátt í ákvörðunum um mikilvæg málefni og áherslu peirra á að millistjórnendur og kennarar væru leiðandi um próun kennsluhátta. Niðurstöðurnar voru talsvert afgerandi um áherslur skólastjóranna en peir leggja almennt mikla áherslu á samstarf við millistjórnendur og kennara og að peir taki pátt í ákvörðunum um mikilvæg málefni.

Dessa niðurstöðu má líta á sem afar jákvæða en nútíma hugmyndir um stjórnun leggja áherslu á samstarf, samrád og pátttöku starfsfólks (Mourshed o.fl., 2010; Woolfolk-Hoy og Hoy, 2009) og að skila árangursríku skólastarfi (Anrig, 2015; McCarthy og Rubinstein, 2017; Rubinstein, 2013-2014). Gildi pessarar áherslu liggur svo í samsömun starfsfólks við hlutverk sitt og samlegðaráhrifum við lausn vandamála. Tengsl við starfsfólk geta pó verið mismunandi og haft ólík áhrif í próun starfshátta. Hafa skal í huga að niðurstöður pessara rannsóknar byggjast á mati skólastjóra um eigin áherslur og tíma sem peir telja sig verja til samstarfs.

Umræðu um niðurstöðurnar er skipt í tvo hluta; virkjun millistjórnenda annars vegar og virkjun kennara hins vegar. 


\section{Virkjun millistjórnenda}

Dreifing forystu hefur verið ráðandi áhersla í fræðilegum skrifum og stefnumörkun um stjórnun og forystu í skólastarfi í talsverðan tíma. Að mati Bush (2013) er dreifing forystu meginfyrirmynd um heim allan sem áhersla um ákjósanlega stjórnunarhætti í skólum. Hann segir hvatann m.a. felast í pví að skólastjórar séu ofhlaðnir störfum og pví nauðsynlegt að dreifa verkefnum og ábyrgð. Dessa áherslu má aftur á móti túlka á tvo vegu, p.e. sem leið til að spara kostnað í rekstri skóla eða sem leið til að auka gæði í skólastarfi.

Hér á landi er ein helsta birtingarmynd pessarar áherslu tilkoma formlegra millistjórnenda í grunnskólum í kjölfar kjarasamninganna 2001 en par voru sampykkt ákvæði um heimildir til að fjölga stjórnendum. Nú eru starfandi deildarstjórar í formlegum stöðum í flestum stærri grunnskólum, sumir í fullu starfi og aðrir í hlutastöðum. Niðurstöður pessarar rannsóknar benda til pess að skólastjórar leggi almennt mikla áherslu á samstarf við deildarstjóra sem millistjórnendur, að peir taki pátt í ákvörðunum um mikilvæg málefni í skólastarfi og séu leiðandi um próun kennsluhátta. Athygli vekur að pessi áhersla er mikil og almenn en enginn breytileiki kom fram á grundvelli peirra bakgrunnsbreyta sem notaðar voru við greiningu niðurstaðna.

Niðurstöður fyrri rannsókna hér á landi á sýn skólastjóra á hlutverk millistjórnenda eru af svipuðum toga og pessi rannsókn leiðir í ljós. Rannsóknarverkefnið Starfshoettir í grunnskólum við upphaf 21. aldar leiddi t.a.m. í ljós almenna ánægju meðal kennara með stjórnunarhætti almennt sem og störf deildarstjóra (Börkur Hansen og Steinunn Helga Lárusdóttir, 2014). Rannsókn sömu höfunda (2016) á störfum deildarstjóra í grunnskólum leiddi í ljós að störf peirra eru fjölbreytt og erilsöm og vel metin af samkennurum en svo virðist sem hlutverk peirra beinist meira að umsýslu en að veita forystu á sviði náms og kennslu.

Gagnrýni Gunter, Hall og Bragg (2013) í pá veru að dreifing forystu sé blekkingarleikur, par sem millistjórnendum sé talin trú um að peir séu aðilar að pátttökumiðaðri stjórnun og kennurum séu falin stjórnunarstörf án fjárhagslegrar umbunar, á pví varla við í pví samhengi sem hér um ræðir. Gagnrýnin snýst pví frekar um hvernig skólastjórar virkja deildarstjóra um próun kennsluhátta.

Tian, Risku og Collin (2016) segja að rannsóknir síðustu ára bendi til ávinnings af framlagi kennara sem gerast millistjórnendur. Rannsókn Louis, Leithwood, Wahlstrom og Anderson (2010) leiddi t.a.m. í ljós að forysta meðal starfsfólks í heild sinni (e. collective leadership) hafði meiri tengsl við góðan árangur en forysta hjá einstaklingum (e. individual leadership). Pátttaka og hlutdeild í ákvörðunum í peim skólum sem flokkuðust sem góðir (e. high performing) var mun meiri en í peim skólum sem flokkuðust sem slakir (e. low performing).

Dessar niðurstöður um hlutdeild og forystu skipta máli fyrir próun hlutverks deildarstjóra í grunnskólum. Mikilvægt er að skólastjórar horfi gagnrýnið á hvert markmiðið er með störfum deildarstjóra, p.e. hvort pað sé einkum til að létta vinnuálagi af skólastjórum eða til að dreifa forystu um próun náms og kennslu.

\section{Virkjun kennara}

Síðustu áratugi hefur mikið verið skrifað um kennara sem lykilaðila í að próa skólastarf áfram (Börkur Hansen og Steinunn Helga Lárusdóttir, 2014; Birky o.fl., 2006; Katzenmeyer og Moller, 2001; Starratt, 1995). Rannsóknir sýna að pessi afstaða er ríkjandi meðal íslenskra skólastjóra (Börkur Hansen og Steinunn Helga Lárusdóttir, 2014). Pær benda til að skólastjórar leggi mikla áherslu á að virkja kennara til að veita kennslufræðilega forystu í sínum skólum. Dá er átt við forystu um málefni sem taka til skólastarfsins almennt. Niðurstöður pessarar rannsóknar sýna að nánast allir skólastjórarnir, eða 94\%, segjast leggja mikla eða mjög mikla áherslu á að einstakir kennarar séu leiðandi um próun kennslu. Sama máli gegnir um pátttöku í ákvörðunum um mikilvæg málefni pví 96\% skólastjóranna segjast leggja mikla eða mjög mikla áherslu að kennarar taki pátt í ákvörðunum um mikilvæg málefni. Einnig segjast skólastjórarnir verja miklum eða mjög miklum tíma í samstarf við kennara, eða 79\%. 
Рað vekur á hinn bóginn athygli að allstór hópur skólastjóra, eða 64\% peirra, segist purfa að leggja mikið eða mjög mikið á sig til að virkja kennara til forystu utan kennslustofunnar. Pá er athyglisvert að marktækur munur kom hvergi fram við greiningu niðurstaðna á grundvelli bakgrunnsbreytna. Ætla mætti að par sem teymiskennsla er ríkjandi kennsluskipulag væri auðveldara að virkja kennara til forystu um verkefni utan kennslustofunnar en í hefðbundnu skipulagi. Sú niðurstaða að aðstæður virðast ekki skipta máli gefur vísbendingar um að pað sé almennt nokkurri tregðu bundið að virkja kennara til forystuhlutverka utan kennslustofunnar.

Í rannsókninni Starfshettir í grunnskólum við upphaf 21. aldar komu fram svipaðar niðurstöður. Dar nefnir t.d. einn skólastjóri að pað sé pungur róður að virkja kennara til að taka pátt í próunarverkefnum og að próa starfshætti sína. Hann benti jafnframt á að pátttaka í próunarverkefnum kallaði ævinlega á aukna vinnu og pá kæmi upp spurningin hver borgaði fyrir hana. Annar skólastjóri kvað suma kennara vera að „nálgast svona einhver pægindahjólför“ (bls. 101) og slík afstaða fæli ekki í sér mikla umbótahugsun (Börkur Hansen og Steinunn Helga Lárusdóttir, 2014). Detta eru vísbendingar um að einhverrar tregðu gæti hjá kennurum að taka að sér forystuhlutverk. Dessar niðurstöður eru í samræmi við margar erlendar rannsóknir sem beinast að virkjun og hlutdeild kennara í próunarstarfi (Day og Harris, 2002; Fullan, 2007).

Á pessu eru vafalaust ýmsar skýringar. Vitað er að meðalaldur kennara við íslenska grunnskóla er hár og hefur farið hækkandi síðustu tvo áratugi (Hagstofa Íslands, 2017). Einhverjir kunna pví að vera orðnir preyttir í starfi sem tekið hefur sífelldum breytingum síðustu árin ásamt auknum kröfum um árangur. Álag er án efa mikið og pví hætta á að fólk brenni út. Hjördís Sigursteinsdóttir (2018) gerði rannsókn á líðan og starfsaðstæðum í leik- og grunnskólum. Niðurstöður sýndu að rúmlega 35\% leik- og grunnskólakennara töldu sig vera oft eða frekar oft stressaða í lok vinnudags og um helmingi peirra fannst peir hafa verið mjög oft eða frekar oft úrvinda í lok vinnudags undanfarna 3 mánuði. Svipaðar niðurstöður komu fram í rannsókn á vinnufyrirkomulagi og líðan í kjölfar kreppu (Guðbjörg Linda Rafnsdóttir og Ásta Snorradóttir, 2014). Í henni kom fram að fjármálahrunið 2008 jók vanlíðan, veikindafjarvistir og samskiptavandamál meðal fjölmargra starfsstétta, par með talið kennara við leik- og grunnskóla.

Við slíkar aðstæður verður að teljast eðlilegt að kennarar séu tregir til að bæta við sig vinnu án pess jafnvel að fá greitt fyrir. Bresku fræðimennirnir Gunter, Hall og Bragg (2013) hafa haldið pví fram að kennurum séu falin stjórnunarstörf til að draga úr vinnuálagi skólastjóra án pess fá greitt fyrir. Deir hafa einnig gagnrýnt að kennarar séu fyrst og fremst ódýrt vinnuafl kvenna sem taki á sig aukna ábyrgð án greiðslu. Undir petta sjónarmið tekur Lumby (2013) sem telur að breskir kennarar bæti sífellt á sig verkefnum án viðbótarlauna. Ekkert er hægt að fullyrða um hvort og pá að hvaða marki launamál skýra pað sem skólastjórar upplifa sem tregðu íslenskra kennara til forystustarfa.

Nauðsynlegt er að grafast fyrir um hvaða pættir í starfi kennara kunni að draga úr áhuga peirra á að vera í forystuhlutverki um mál sem varða skólann í heild en rannsóknir sýna að peirra framlag skiptir sköpum um árangur í skólastarfi (Anrig, 2015; McCarthy og Rubinstein, 2017; Rubinstein, 2013-2014). Kennarar eru í yfirburðastöðu til að greina og skilja parfir nemenda og hverju purfi að breyta í starfsháttum skóla til að mæta peim. Forysta peirra í kennslufræðilegum málefnum og pátttaka peirra í mikilvægum ákvörðunum er pví mikilvæg til að hægt sé að hámarka tækifæri nemenda til menntunar.

Ekki er sjálfgefið að íslenskir skólastjórar búi yfir nauðsynlegri pekkingu til að virkja kennara. Harris (2014) minnir á að sumir skólastjórar telji að peir verði valdaminni ef peir dreifa valdi til peirra. Sá ótti sé á hinn bóginn ástæðulaus pví rannsóknir bendi til hins gagnstæða enda styrki valddreifing stofnunina. Rannsóknir á samvinnu kennara í dreifðu stjórnskipulagi (Schribner, Sawyer, Watson og Myers, 2007) benda einmitt til pess að skólastjórar purfi aðstoð við að skilja betur pað hlutverk sitt að setja vinnuteymum markmið og ákvarða umfang sjálfstæðis peirra. 


\section{Collaboration with middle leaders and teachers leadership emphasis of compulsory school principals in Iceland}

Current theories on school leadership focus on principals' vision of their role and their relations with school personnel. More specifically, school leadership is now viewed as a collaborative effort between principals and teachers in providing leadership in the area of teaching and learning (Harris, 2008; Kaplan \& Owings, 2015; Louis, Leithwood, Wahlstrom \& Anderson, 2010; Robinson, 2011; Sergiovanni, 2009). The main objective of this emphasis on collaboration is to contribute to improved educational quality in schools (Hoy \& Miskel, 2008; Sergiovanni, 2009; Woolfolk-Hoy $\&$ Hoy, 2009). This paper reports on a study of the leadership emphasis compulsory school principals in Iceland place on collaboration with middle leaders and teachers. The focus is on two forms of collaborative leadership, prominent in the 21st century, distributed leadership and teacher leadership.

The study was conducted in 2017. Data was gathered with an electronic questionnaire sent to all Icelandic compulsory school principals, 162 individuals, in the spring of 2017. The number of respondents was 111 , making the response rate $69 \%$. The questionnaire was designed and administered by means of the Qualtrics software system and data analysis was conducted using the SPSS and EXCEL programs. The principals were asked to estimate, on a five point Likert scale, the time they devote to working with middle leaders, teachers, and other school staff. They were also asked to estimate their emphasis on involving middle leaders in decision-making on significant issues in their schools. Furthermore, they were asked to estimate their emphasis on middle leaders and teachers providing leadership concerning the development of teaching and learning.

The following background information was used for analysing the data: background variables concerning the principals' age, gender, education, experience as principal, experience as assistant principal; background variables concerning circumstances within the schools, such as their size (number of students), location (urban, rural), dominant teaching arrangements (classroom teaching, team teaching, combination of classroom and team teaching), number of students with severe learning difficulties, number of support staff. The analysis was based on the assumption that these variables would signify a difference in the working environment of the principals.

The findings show that principals claim to devote considerable time to collaborating with teachers (79\%), middle leaders (59\%) and other staff (48\%). Moreover, the findings show that the principals claim they strongly emphasise the involvement of teachers $(96 \%)$ and middle leaders $(74 \%)$ in decision-making concerning significant issues in their schools. However, $25 \%$ of the principals considered this question concerning involvement of middle leaders in decision-making irrelevant because no formal middle leader position existed in their schools. The findings also show that the principals emphasise involvement of teachers (94\%) and middle leaders (66\%) in providing leadership in the area of teaching and learning. Again, a quarter (26\%) of the principals considered the question concerning the leadership of middle leaders irrelevant because no formal leaders existed in their schools. Lastly, about two thirds (64\%) of the principals claim it requires much effort to involve teachers in taking responsibilities in school activities outside their classrooms. The analysis of the data showed no significant differences relating to any of the questions concerning time for collaboration, involvement in decision-making, providing leadership or effort concerning involvement, based on the background variables listed above. 
While the principals want middle leaders to lead the development of teaching and learning, it seems as if their tasks are more in the area of operational components to the detriment of pedagogical and instructional issues. Principals, therefore, need to ask themselves critical questions as to what is the objective of the role of middle leaders; that is, whether it is to decrease their own work load or to facilitate the development of teaching and learning. It is also important to analyse whether it is workload, salaries or other work-related issues that discourage teachers from contributing to the overall leadership of the schools.

Keywords: Principals, compulsory schools, distributed leadership, teacher leadership

\section{Um höfundana}

Börkur Hansen (borkur@hi.is) er prófessor við Deild kennslu- og menntunarfræði á Menntavísindasviði Háskóla Íslands. Hann lauk B.A.-prófi í uppeldis- og sálfræði frá Háskóla Íslands árið 1982, M.Ed.-prófi í menntastjórnun frá Háskólanum í Alberta árið 1984 og doktorsprófi frá sama skóla árið 1987. Rannsóknir hans hafa einkum beinst að skólastjórnun, skólapróun og stjórnskipulagi skóla.

Steinunn Helga Lárusdóttir (shl@hi.is) er prófessor emerita við Deild kennslu- og menntunarfræði á Menntavísindasviði Háskóla Íslands. Hún lauk kennaraprófi frá Kennaraháskóla Íslands árið 1975, M.Ed.-prófi í menntastjórnun frá Háskólanum í Illinois, Urbana-Champaign árið 1982 og doktorsprófi í stjórnun menntastofnana frá Lundúnaháskóla 2008. Rannsóknir hennar hafa einkum beinst að skólastjórnun, jafnrétti og kyngervi. Steinunn Helga er fyrrverandi formaður Rannsóknarstofu í menntastjórnun, nýsköpun og mati á skólastarfi.

\section{About the authors}

Börkur Hansen (borkur@hi.is) is a professor at the School of Education, University of Iceland. He completed a B.A. in education and psychology from the University of Iceland in 1982, an M.Ed. from the University of Alberta in 1984 and a Ph.D. in 1987. His major research interests are in the areas of leadership, school management, school development and educational governance.

Steinunn Helga Lárusdóttir (shl@hi.is) is professor emerita at the School of Education, University of Iceland. She completed an M.Ed. in educational administration from the University of Illinois in 1982 and a Ph.D. in educational administration from the Institute of Education, University of London, in 2008. Her research is in the areas of school leadership and administration, values, gender and equality. She is a former Chair of the Center for Research in Educational Leadership and Program Evaluation. 


\section{Heimildir}

Akert, N. og Martin, N. (2012). The role of teacher leaders in school improvement through the perceptions of principals and teachers. International Journal of Education, 4(4), 284-299. doi:10.5296/ije.v4i4.2290

Anrig, G. (2015). How we know collaboration works. Educational Leadership, 72(5), 30-35.

Ash, R. C. og Persall, J. M. (2000, maí). The principal as chief learning officer: Developing teacher leaders. NASSP Bulletin, 84(616), 15-22.

Birky,V.D., Shelton, M. og Headley, S. (2006, júní). An administrator's challenge: Encouraging teachers to be leaders. NASSP Bulletin, 90(2), 87-101. doi:10.1177/0192636506290155

Branson, C. M., Franken, M. og Penney, D. (2016). Middle leadership in higher education: A relational analysis. Educational Management, Administration and Leadership, 44(1), 128-145. doi:10.1177/1741143214558575

Bush, T. (2013). Distributed leadership: The model of choice in the 21st century. Educational Management, Administration and Leadership, 4(5), 543-544. doi:10.1177/1741143213489497

Busher, H., Hammersley-Fletcher, L. og Turner, C. (2007). Making sense of middle leadership, community, power and practice. School Leadership and Management, 27(5), 405-422. doi:10.1080/13632430701606061

Börkur Hansen. (2013). Forysta og skólastarf. Í Rúnar Sigpórsson, Rósa Eggertsdóttir og Guðmundur Heiðar Frímannsson (ritstjórar), Fagmennska í skólastarfi: Skrifað til heiðurs Trausta Dorsteinssyni (bls. 77-92). Reykjavík: Háskólaútgáfan.

Börkur Hansen, Ólafur H.Jóhannsson og Steinunn Helga Lárusdóttir. (2008). Breytingar á hlutverki skólastjóra í grunnskólum - kröfur, mótsagnir og togstreita. Uppeldi og menntun, 17(2), 87-104.

Börkur Hansen og Steinunn Helga Lárusdóttir. (2014). Stjórnun og skipulag. Í Gerður G. Óskarsdóttir (ritstjóri). Starfshattir í grunnskólum við upphaf 21. aldar (bls. 87-112). Reykjavík: Háskólaútgáfan.

Börkur Hansen og Steinunn Helga Lárusdóttir. (2016). Störf deildarstjóra í grunnskólum - verkefni og áherslur. Netla-Veftímarit um uppeldi og menntun. Sótt af http://netla.hi.is/greinar/2016/ryn/06_ryn_arsrit_2016.pdf

Danielson, C. (2006). Teacher leadership that strengthens professional practice. Alexandria,VA: ASCD.

Day, C. og Harris, A. (2002). Teacher leadership, reflective practice and school improvement. Í Leithwood, P. og Hallinger, K. (ritstjórar). Second international handbook of educational leadership and administration (bls. 957-977). Dordrecht: Kluwer Academic Publishers.

Fitzgerald, T. og Gunter, H. M. (2008). Contesting the orthodoxy of teacher leadership. International Journal of Leadership in Education, 11(4), 331-340. doi:10.1080/13603120802317883

Fullan, M. (2007). The new meaning of educational change (4. útgáfa). London: Routledge.

Guðbjörg Linda Rafnsdóttir og Ásta Snorradóttir. (2014).Vinnufyrirkomulag og líðan í kjölfar kreppu.Yfirlitsgrein. Íslenska pjóðfélagið, 5(2), 39-55.

Gunter, H., Hall, D. og Bragg, J. (2013). Distributed leadership:A study in knowledge production. Educational Management, Administration and Leadership, 41(5), 555-580. doi:10.1177/1741143213488586

Hagstofa Íslands. (2017, 28. júlí). Meðalaldur kennara í grunnskólum heldur áfram að heekea. Sótt af https:// hagstofa.is/utgafur/frettasafn/menntun/nemendur-og-starfsfolk-i-grunnskolum-haustid-2016/

Hall, D., Gunter, H. M. og Bragg, J. (2012). Leadership, new public management and the re-modeling and regulation of teacher identities. International Journal of Leadership in Education, 16(2), 173-190. doi:10.108 0/13603124.2012.688875

Hargreaves, A. og Fink, D. (2008). Sustainable leadership. San Francisco: Jossey-Bass.

Harris, A. (2008). Distributed leadership:According to the evidence. Journal of Educational Administration, 40(2), 172-188. doi:10.1108/09578230810863253

Harris, A. (2013). Distributed leadership. Friend or foe? Educational Management, Leadership and Administration, 4(5), 545-554. doi:10.1177/1741143213497635

Harris, A. (2014). Distributed leadership matters. Perspectives, practicalities, and potential. Thousand Oaks, CA: Corwin.

Hartley, D. (2010). Paradigms: How far does research in distributed leadership 'stretch'? Educational Management, Administration and Leadership, 38(3), 271-285. doi:10.1177/1741143209359716

Hjördís Sigursteinsdóttir. (2018). Líðan í lok vinnudags - um starfsaðstæður leik- og grunnskólakennara. Rádstefnurit Netlu - Menntakvika 2018. Sótt af http://netla.hi.is/serrit/2018/menntakvika_2018/03.pdf

Hoy,W. K. og Miskel, C. G. (2008). Educational administration. Theory, research and practice (8. útgáfa). New York: McGraw-Hill. 
Jón Páll Haraldsson. (2015). Áherslur i stjórnun. Dreifð forysta í reykvískum grunnskólum (óútgefin meistararitgerð). Háskóli Íslands, Reykjavík.

Júlíana Hauksdóttir. (2012). Tvöfalt hlutverk deildarstjóra. Samstarf við kennara og skólastjórnendur (oútgefin meistararitgerð). Háskóli Íslands, Reykjavík.

Katzenmeyer, M. og Moller, G. (2001). Awakening the sleeping giant. Helping teachers develop as leaders (2. útgáfa). Thousand Oaks, CA: Corwin.

Kjarasamingur Kennarasambands Íslands og fjármálaráđherra f.h. ríkissjóðs. Gildistími 7. janúar 2001 til 30. apríl 2004. Gefið út af Kennarasambandi Íslands og starfsmannaskrifstofu fjármáráðuneytisins í mars 2002.

Kjarasamningur kennara og sveitarfélaganna sem undirritaður var 2001. Miklar kerfisbreytingar og meira vald til skólanna. (2004, 29. september). Morgunblaðið, sótt af https://www.mbl.is/greinasafn/grein/820941/

Louis, K. S., Leithwood, K., Wahlstrom, K. L. og Anderson, S. E. (2010). Investigating the links to improved student learning: Final report of research findings. St. Paul:The University of Minnesota.

Lumby,J. (2013). Distributed leadership:The uses and abuses of power. Educational Management Administration and Leadership, 41(5), 581-597. doi:10.1177/1741143213489288

Lög um grunnskóla nr. 66/1995.

McCarthy, J. E. og Rubinstein, S.A. (2017). National study on union-management partnerships and educator collaboration in US public schools. Collaborative school leadership working paper. Sótt af https://www.cecweb. org/wp content/uploads/2017/10/Union_Management_Partnerships.pdf

Mourshed, M., Chijioke, C. og Barber, M. (2010). How the world's most improved school systems keep getting better. Washington, D.C.: McKinsey and Company.

Muijs, D. og Harris, A. (2003). Teacher leadership - improvement through empowerment. An overview of the literature. Educational Management E Administration, 31(4), 437-448. doi:10.1177/0263211X030314007

Patterson, J. og Patterson, J. (2004). Sharing the lead. Educational Leadership, 61(7), 74-78.

Rubinstein, S.A. (2013-2014). Strengthening partnerships. How communication and collaboration contribute to school improvement. American Educator, 37(4), 22-28.

Schribner, J. P., Sawyer, R. K., Watson, S. T. og Myers, W. L. (2007). Teacher teams and distributed leadership: A study of group discourses and collaboration. Educational Administration Quarterly, 43(1), 67-100. doi:10.1177/0013161X06293631

Sergiovanni, T. J. (2009). The principalship. A reflective practice perspective (6. útgáfa). Boston: Pearson.

Sigríður Anna Guðjónsdóttir, Amalía Björnsdóttir og Ólafur H. Jóhannsson. (2007). Deildarstjórar í grunnskólum. Hver er afstaða skólastjóra og kennara til deildarstjórastarfsins, hlutverks pess og mikilvægis? Netla - Veftímarit um uppeldi og menntun. Sótt af http://netla.hi.is/greinar/2007/008/index.htm

Spillane, J. P. (2005). Distributed leadership. Educational Forum, 69(2), 143-150.

Spillane, J. P. (2006). Distributed leadership. San Francisco, CA: Jossey-Bass.

Starratt, R. J. (1995). Leaders with vision: The quest for school renewal. Thousand Oaks, CA: Corwin Press.

Steinunn Helga Lárusdóttir og O’Connor, E. (2017). Distributed leadership and middle leadership practice in schools: A disconnect? Irish Educational Studies, 36(4), 423-438. doi:10.1080/03323315.2017.1333444

Tian, M., Risku, M. og Collin, K. (2016). A meta-analysis of distributed leadership from 2002 to 2013. Theory development, empirical evidence and future research focus. Educational Management, Administration and Leadership, 44(1), 146-164. doi:10.1177/1741143214558576

Woolfolk-Hoy, A. og Hoy, W. K. (2009). Instructional leadership: A learning-centered guide to learning schools. Boston: Pearson.

York-Barr, J. og Duke, K. (2004). What do we know about teacher leadership? Findings from two decades of scholarship. Review of Educational Research, 74(3), 255-316. doi:10.3102/00346543074003255

Börkur Hansen og Steinunn Helga Lárusdóttir (2019).

Forysta sem samstarfsverkefni: Áhersla skólastjóra á valddreifingu og samstarf

Netla - Veftímarit um uppeldi og menntun. Menntavísindasvið Háskóla Íslands.

Sótt af http://netla.hi.is/greinar/2019/ryn/14

DOI: https://doi.org/10.24270/netla.2019.14 